\title{
Clustered organization and transcriptional analysis of a family of five csp genes of Lactococcus lactis MG1363
}

\author{
Jeroen A. Wouters, ${ }^{1,2}$ Jan-Willem Sanders, ${ }^{3}$ Jan Kok, ${ }^{3}$ Willem M. de Vos, ${ }^{1}$ \\ Oscar P. Kuipers' ${ }^{1}$ and Tjakko Abee ${ }^{2}$
}

Author for correspondence: Oscar P. Kuipers. Tel: +31 318 659525. Fax: +31318650400. e-mail : kuipers@nizo.nl

\footnotetext{
1 Microbial Ingredients Section, NIZO Food Research, PO Box 20,6710 BA Ede, The Netherlands

2 Laboratory for Food Microbiology, Food Science Group, Wageningen University and Research Center, Wageningen, The Netherlands

3 Department of Genetics, Groningen University, Haren, The Netherlands
}

\begin{abstract}
A family of genes encoding cold-shock proteins, named cspA, cspB, cspC, cspD and cspE, was cloned and sequenced from Lactococcus lactis MG1363. The genes cspA and cspB and the genes cspC and CspD are located in tandem repeats, an organization of csp genes that has never been encountered before. The five genes encode small (7.1-7.6 kDa) proteins with high mutual sequence identities (up to $85 \%$ ) and high identities (about 45-65\%) with the major coldshock proteins from Escherichia coli (CspA) and Bacillus subtilis (CspB). Northern-blot analysis revealed single transcripts of about 300 nucleotides for each csp gene and showed that $\operatorname{csp} A, \operatorname{cspB}, \operatorname{csp} C$ and $\operatorname{cspD}$ mRNA levels were strongly increased upon cold shock to $10^{\circ} \mathrm{C}$ (about 10-, 40-, 10- and 30-fold compared to $30^{\circ} \mathrm{C}$, respectively), whereas the cspE mRNA level was not increased. The expression of the cold-induced csp genes was highest in the 6-8 $\mathrm{h}$ lag phase after cold shock. A differential expression in time, in which csp $A$ and cspC were maximally expressed at $2 h$ and $\operatorname{csp} B$ and cspD at $4 \mathrm{~h}$ after cold shock, was observed. The -35 and -10 regions of the five promoters were identified and transcriptional start sites were mapped in each case by primer extension at different temperatures which confirmed that regulation takes place at the transcriptional level. Significant differences were observed between the 5 -untranslated leader regions of the four cold-induced csp genes and the corresponding region of the non-cold-induced cspE gene.
\end{abstract}

Keywords: $c s p$ genes, low-temperature adaptation, transcription, Lactococcus lactis

\section{INTRODUCTION}

Lactococcus lactis plays an important role in many dairy fermentations. During processing and ripening of fermented dairy products these bacteria have to deal with different environmental stresses, such as low $\mathrm{pH}$, high salt concentrations and temperature extremes (Rallu et al., 1996). Several stress responses of $L$. lactis have been studied and stress-induced genes could be identified (Rallu et al., 1996; Sanders et al., 1995; Van Asseldonk et al., 1993). However, low temperature stress has received less attention. Cold stress might be important

Abbreviations: CSP, cold-shock protein; UTR, untranslated leader region. The EMBL accession numbers for the sequences reported in this paper are Y17215 (for cspA and cspB), Y17216 (for cspC and cspD) and Y17217 (for (spE). for the survival of starter cultures after frozen storage and for fermentations taking place at low temperatures.

The response to cold shock has been extensively studied in Escherichia coli and has been shown to result in the induction of a specific set of 14 proteins. These proteins play a role in various cellular processes and include, among others, NusA, RecA, H-NS, GyrA, polynucleotide phosphorylase and CspA (further referred to as $\operatorname{CspA}^{\mathrm{E}}$ ) (Jones et al., 1987, 1996; Jones \& Inouye, 1994, 1996). Maximal induction after cold shock was detected for $\operatorname{CspA}{ }^{\mathrm{E}}$, which is transiently overexpressed (200-fold induction) and then represents $13 \%$ of the newly synthesized proteins (Goldstein et al., 1990; Jones et al., 1987). A highly similar protein, CspB (further referred to as $\mathrm{CspB}^{\mathrm{B}}$ ), has been described in Bacillus subtilis (Willimsky et al., 1992).

$\operatorname{CspA}^{\mathrm{E}}$ (Goldstein et al., 1990) and CspB ${ }^{\mathrm{B}}$ (Willimsky et 
al., 1992) are small proteins with a molecular mass of $7.4 \mathrm{kDa}$ and a low isoelectric point (pI 5.9 and 4.3 , respectively). $\mathrm{CspA}^{\mathrm{E}}$ acts as a transcriptional activator of at least two other genes encoding the cold-induced proteins GyrA (Jones et al., 1992) and H-NS (LaTeana et al., 1991), both involved in DNA supercoiling. The crystal structures of $\mathrm{CspA}^{\mathrm{E}}$ and $\mathrm{CspB}^{\mathrm{B}}$ have been resolved and both proteins are able to bind specifically to single-stranded DNA containing a Y-box motif (ATTGG) or its complementary sequence (CCAAT) (Graumann \& Marahiel, 1994; Newkirk et al., 1994; Schindelin et al., 1994). Cold-shock proteins (CSPs) contain sequence regions highly homologous to the cold-shock domain of eukaryotic DNA-binding proteins, designated Y-box factors (Landsman, 1992). $\mathrm{CspA}^{\mathrm{E}}$ and $\mathrm{CspB}^{\mathrm{B}}$ are also considered to be RNAbinding proteins because they both possess highly conserved RNA-binding motifs, i.e. RNP-1 (ribonucleoprotein) and a rudimentary RNP-2 motif (Jones \& Inouye, 1994; Schindelin et al., 1993), and it appears that $\mathrm{CspA}^{\mathrm{E}}$ can act as an RNA chaperone (Jiang et al., 1997). For $\mathrm{CspB}^{\mathrm{B}}$ a function as an anti-freeze protein has been suggested because a lower survival has been observed after freezing of cells in which the $\operatorname{csp} B$ gene was disrupted (Willimsky et al., 1992). The regulation of the synthesis of the major CSPs is still unclear but it seems to take place at the level of both transcription (Lee et al., 1994) and translation (Brandi et al., 1996). Recently, it was shown that the abundant presence of $C \operatorname{spA}{ }^{\mathrm{E}}$ after cold shock is due to increased stability of its mRNA at low temperature (Fang et al., 1997).

In E. coli, B. subtilis and Bacillus cereus, families of csp genes of respectively nine, three and six members have been found (Graumann et al., 1996; Lee et al., 1994; Mayr et al., 1996; Nakashima et al., 1996; Yamanaka \& Inouye, 1997). In $E$. coli at least three of the nine identified csp genes are cold induced (Lee et al., 1994; Nakashima et al., 1996). The csp genes of E. coli appeared to be scattered on the chromosome (Lee $e t$ al., 1994) and also for other bacteria only non-clustered $c s p$ genes have been reported (Graumann et al., 1996; Mayr et al., 1996). A recent study by Graumann et al. (1997) using a triple $c s p$ deletion mutant of $B$. subtilis revealed that CSPs are essential for cellular growth and for efficient protein synthesis at both optimal and low temperatures.

The cold-shock response of $L$. lactis IL1403 was studied by Panoff et al. (1994), revealing that 12 proteins were overexpressed after cold shock. Recently, one coldinduced $c s p$ gene was identified in L. lactis (ChapotChartier et al., 1997; Kim \& Dunn, 1997) and two in another lactic acid bacterium, Lactobacillus plantarum (Mayo et al., 1997).

In this study, a family of five genes encoding CSPs of L. lactis MG1363 was characterized. A clustered organization of $c s p$ genes has been observed for the first time: two tandems of two csp genes. Transcriptional analysis of the L. lactis csp genes revealed cold induction for four of these genes and a differential expression of the respective genes during the adaptation phase after cold shock.

\section{METHODS}

Bacterial strains and growth conditions. E. coli MC1061 (Casadaban \& Cohen, 1980) was used as a host strain in cloning experiments and was grown in Tryptone Yeast (TY) medium with aeration at $37^{\circ} \mathrm{C}$ (Sambrook et al., 1989). Antibiotics were used in the following concentrations: ampicillin $50 \mu \mathrm{g} \mathrm{ml}^{-1}$; chloramphenicol $10 \mu \mathrm{g} \mathrm{ml}^{-1}$. L. lactis MG1363, a plasmid-free and prophage-cured derivative of $L$. lactis NCDO 712 (Gasson, 1983), was grown in M17 broth (Difco) supplemented with $0.5 \%(\mathrm{w} / \mathrm{v})$ glucose at $30^{\circ} \mathrm{C}$ without aeration. Growth curves of $L$. lactis were obtained by measuring the $\mathrm{OD}_{600}$ at various time points by diluting the sample fourfold in M17 broth.

DNA techniques and sequencing. Chromosomal DNA of $L$. lactis was isolated as described previously (Vos et al., 1989). L. lactis cells were transformed by electroporation (Wells et al., 1993). E. coli cells were transformed by the $\mathrm{CaCl}_{2}$ procedure and plasmid isolations were carried out according to established procedures (Sambrook et al., 1989). E. coli plasmid DNA was isolated on a large scale using Qiagen columns. Restriction enzymes, T4 DNA ligase and other DNAmodifying enzymes were purchased from Gibco-BRL Life Technologies, New England Biolabs or Promega and used as recommended by the manufacturers. Cloning procedures, radiolabelling of DNA fragments, agarose gel electrophoresis and Southern-blot hybridizations were performed according to established procedures (Sambrook et al., 1989). DNA fragments were isolated from agarose gels by using the GlassMAX DNA Isolation Matrix System (BRL Life Technologies). PCR was carried out according to conditions described previously (Kuipers et al., 1991). Nucleotide sequences of plasmid DNA were analysed with an ALF automatic sequencer (Pharmacia Biotech) in combination with an AutoRead sequencing kit (Pharmacia Biotech) with fluorescein-labelled primers. Oligonucleotides used as primers in sequencing reactions, primer extension experiments and PCR, were purchased from Pharmacia Biotech.

Cloning of csp genes. PCR with primers based on homologous regions of $\mathrm{CspA}^{\mathrm{E}}$ (Goldstein et al., 1990) and $\mathrm{CspB}^{\mathrm{B}}$ (Willimsky et al., 1992; Table 2) with chromosomal DNA of L. lactis MG1363 as a template resulted in the amplification of a fragment of about $200 \mathrm{bp}$ (PCR 1) with primers 1 and 2 (both containing an EcoRI site). When primers 3 and 4 were used, a fragment of about $550 \mathrm{bp}$ (PCR2) was amplified. The fragments were cloned in pUC18 (pUC18PCR1) and pGEM-T (purchased from Promega; pGEM-TPCR2), respectively. The fragments were sequenced and appeared to contain parts of putative $c s p$ genes. By use of PCR1 as a probe in Southern hybridization, four hybridizing fragments (HindIII chromosomal DNA digest) were detected (Fig. 1a). The first hybridizing band was cloned as a $3.3 \mathrm{~kb}$ EcoRI-HpaII fragment into the EcoRI and AccI sites (after calf intestine alkaline phosphatase treatment) of pUC19, resulting in pUC19CspA/B (Table 1). The second hybridizing band was cloned as a HindIII-BglII fragment $(2 \cdot 1 \mathrm{~kb})$ in the HindIII- and the BamHI-sites of pUC19 (pUC19CspC/D; Table 1) and sequenced by primer walking. Attempts to clone the third hybridizing fragment either as a $3.5 \mathrm{~kb}$ HindIII fragment or as a $4.5 \mathrm{~kb}$ EcoRI-Sacl fragment in both a high-copy (pUC19) and a low-copy vector (pNZ84, a pACYC derivative; Van Alen-Boerrigter et al., 1991) failed. The fourth hybridizing 
Table 1. Plasmids

\begin{tabular}{|c|c|}
\hline Plasmid & Characteristics \\
\hline pUC18PCR1 & $\begin{array}{l}\text { pUC18 containing a PCR fragment (PCR1) of about } 200 \text { bp obtained } \\
\text { with primers } 1 \text { and } 2\end{array}$ \\
\hline pGEM-TPCR2 & $\begin{array}{l}\text { pGEM-T containing a PCR fragment (PCR2) of about } 550 \text { bp } \\
\text { obtained with primers } 3 \text { and } 4\end{array}$ \\
\hline pUC19CspA/B & $\begin{array}{l}\text { pUC19 containing a } 3.3 \mathrm{~kb} \text { EcoRI-HpaII fragment including } \\
\operatorname{csp} A / \operatorname{csp} B\end{array}$ \\
\hline pUC19CspC/D & $\begin{array}{l}\text { pUC19 containing a } 2 \cdot 1 \mathrm{~kb} H \text { indIII-BglII fragment including } \\
\operatorname{csp} C / \operatorname{csp} D\end{array}$ \\
\hline pUC19CspE & $\begin{array}{l}\text { pUC19 containing a } 1.1 \mathrm{~kb} \text { HindIII-Pst I fragment including } \operatorname{csp} E \text { and } \\
\text { its upstream region }\end{array}$ \\
\hline pLEX & $\begin{array}{l}\text { pUC18 containing a } 0.95 \mathrm{~kb} \text { PCR fragment which is cloned in the } \\
\text { Sau } 3 \mathrm{AI} \text { and Hincll sites including } c s p E \text { and its downstream region }\end{array}$ \\
\hline
\end{tabular}

Table 2. Oligonucleotides

\begin{tabular}{|ll|}
\hline Oligonucleotide & \multicolumn{1}{c|}{ Sequence $\left(\mathbf{5}^{\prime}-\mathbf{3}^{\prime}\right)$} \\
\hline Primer 1 & CGGAATTCGGIA(A/T)IGTIAA(A/G)TGGTT(T/C)AA \\
Primer 2 & CGGAATTCGTIAC(A/G)TTIGCIGC(C/T)TGIGGICC \\
Primer 3 & GGNANNGTNAA(A/G)TGGTT(C/T)AA \\
Primer 4 & (G/A/T)AT(A/G)AANCC(A/G)AANCC(C/T)TT \\
pAMILEX & GAACGCAATGAGTCCTG \\
pAMI4 & TGACAGCGGGCCTAACC \\
PE $c s p A$ & GCCATAGCCTTGTCCATATTG \\
PE $c s p B$ & GCCAAATCCTTTATCTGGA \\
PE $c s p C$ & CTTGCATATCATCTGCCA \\
PE $\operatorname{csp} D$ & ACCAAATCCTTTAGTAGC \\
PE $c s p E$ & TGTGCGAAAACGTCGTTT \\
\hline
\end{tabular}

band was cloned as a HindIII-Pst I fragment $(1 \cdot 1 \mathrm{~kb})$ in the HindIII and PstI sites of pUC19 (pUC19CspE; Table 1). On this fragment a putative csp gene was located; to obtain its downstream region the following inverse PCR strategy was used. Chromosomal DNA was digested with $\mathrm{Hpall}$ and selfligated. PCR was performed with this template and with pAMILEX and pAMI4 (Table 2) as primers. A $950 \mathrm{bp}$ fragment was obtained which was cloned in the blunt HincII and the Bam HI site (compatible with Sau3AI) of pUC18 after digestion with Sau3AI (resulting in pLEX; Table 1).

DNA and deduced protein sequence analysis. Computer analysis of DNA sequences and the deduced amino acid sequences was performed with the programs PC/GENE (version 6.70; IntelliGenetics) and Clone (Version 4.0; Clone Manager). The EMBL/GenBank and SWISS-PROT/PIR databases were used to search for amino acid sequence similarities.

RNA techniques and primer extension experiments. RNA isolation, Northern blotting and subsequent hybridization with radiolabelled probes was performed as described previously (Kuipers et al., 1993). For cold-shock experiments, cultures were grown at $30^{\circ} \mathrm{C}$ to mid-exponential phase, after which they were spun down by centrifugation and resuspended in medium precooled to $10^{\circ} \mathrm{C}$. After exposure to $10^{\circ} \mathrm{C}$ for various time periods $(0,0.5,1,2,4$ and $24 \mathrm{~h}$ ) total
RNA was isolated. The same oligonucleotides were used as probes in Northern blotting and as primers in primer extension experiments (PEcspA to PEcspE; Table 2). Quantification of the $c s p$ transcripts in Northern blotting was performed using the Dynamics Phosphor Imaging System. Cross-hybridization of the probes to the other csp genes was checked using Southern blotting, quantified with the same system. As a control for the RNA quantity the usp45 gene, which is constitutively expressed (Van Asseldonk et al., 1990), was used and correction factors were calculated by using the Phosphor Imaging System. Primer extension experiments on the $c s p$ genes were carried out as described previously (Kuipers et al., 1993), with the same RNA samples as used for Northern blotting. The resulting cDNA was subjected to electrophoresis alongside nucleotide sequencing ladders generated with the same primers using the dideoxy chain-termination method (Sanger et al., 1977) and $\left[\alpha^{32} \mathrm{P}\right] \mathrm{dATP}$ as radiolabel.

\section{RESULTS}

\section{Cloning of genes encoding putative CSPs}

Using different primers based on the homologous sequences of $\mathrm{CspA}^{\mathrm{E}}$ and $\mathrm{CspB}^{\mathrm{B}}$ (Table 2) two PCR products of about $200 \mathrm{bp}$ (PCR1) and 550 (PCR2) bp 


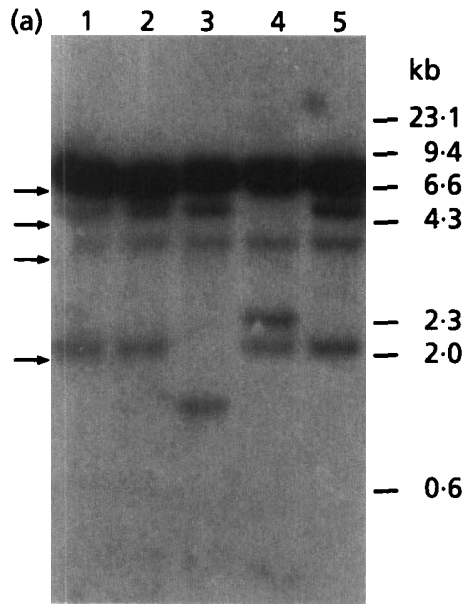

(b)
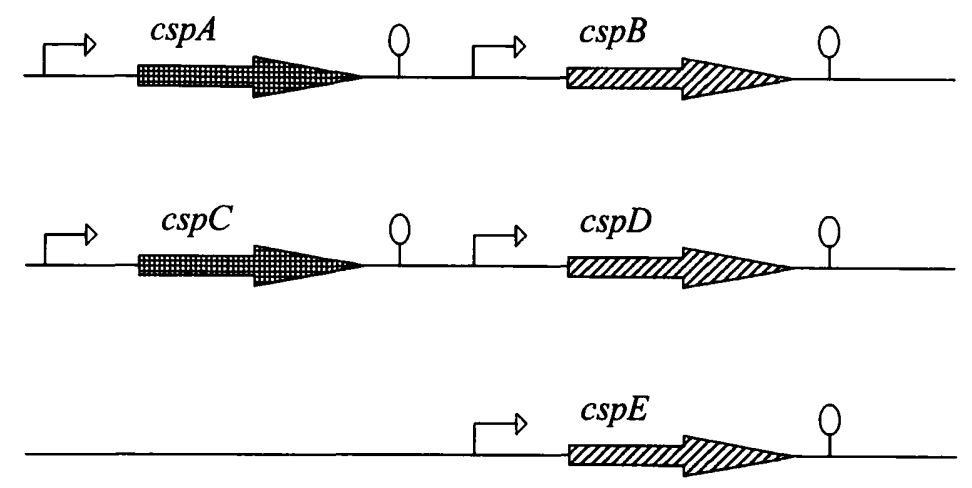

$200 \mathrm{bp}$

\begin{abstract}
Fig. 1. (a) Southern hybridization, with PCR1 used as a probe, of chromosomal DNA of L. lactis MG1363 digested with HindIII (lane 1), HindIII and EcoRI (lane 2), HindIII and PstI (lane 3), HindIII and BgIII (lane 4), and HindIII and BamHI (lane 5). Marker sizes are indicated on the right, and arrows indicate the hybridizing Hindlll fragments. (b) Organization and nomenclature of the csp genes found in L. lactis MG1363. The large arrows indicate the ORFs, the smaller arrows indicate the transcription starts and the major terminators are indicated by a hairpin structure.
\end{abstract}

were amplified with $L$. lactis MG1363 chromosomal DNA as a template. After cloning and sequencing it appeared that these PCR products contained parts of genes homologous to the major $c s p$ genes. In a Southernblotting experiment, using PCR1 as a probe, four hybridizing fragments were detected in different digests of L. lactis chromosomal DNA (Fig. 1a). Two csp genes, named $c s p A$ and $c s p B$, are located on an EcoRI-Hpall fragment (cloned in pUC19 resulting in pUC19CspA/B). Another fragment (cloned in pUC19 resulting in pUC19CspC/D) also contained two csp genes (named $c s p C$ and $c s p D$ ), organized in a tandem repeat. A single csp gene, named $c s p E$ (cloned in pUC19 resulting in pUC19CspE), is located on a HindIII-PstI fragment and its downstream region was cloned by an inverse PCR strategy (pLEX). The organization of the different $c s p$ genes is shown in Fig. 1(b). In Southern hybridization with PCR2 as a probe only two fragments, identical to fragments that hybridized with PCR 1 as a probe, could be detected (data not shown). When the different $c s p$ genes were used as probes in Southern hybridization (different chromosomal-DNA digests) no extra hybridizing bands could be detected compared to the four bands obtained when using PCR 1 as a probe. In an $E c o R I$ digest all $c s p$ homologues were located on only two fragments, indicating a clustered organization on the $L$. lactis MG1363 chromosome. No hybridization was observed using plasmid DNA (isolated from several L. lactis strains) and PCR1 as a probe, indicating that these csp genes are chromosomally encoded and that no homologues are located on plasmids (data not shown).

A remarkably high nucleotide sequence identity was found for the two tandem repeats: $79 \%$ over $800 \mathrm{nt}$ containing both ORFs. In the tandem repeats the first ORFs ( $c s p A$ and $c s p C)$ and the second ORFs ( $c s p B$ and

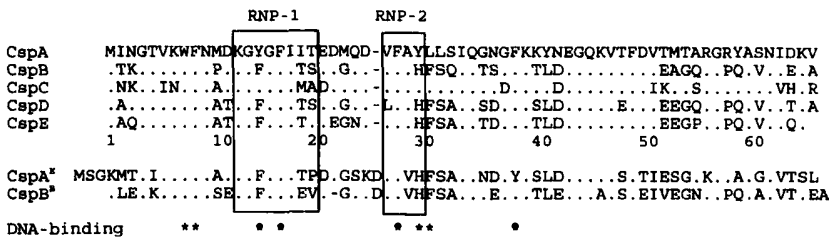

Fig. 2. Alignment of the deduced amino acid sequences of lactococcal CSPs (CspA-CspE) and the amino acid sequences of $\mathrm{CspA}^{\mathrm{E}}$ and $\mathrm{CspB}^{\mathrm{B}}$. Identical amino acids are indicated with dots; gaps are indicated with dashes. Important regions for DNA binding are indicated with asterisks, and RNA-binding motifs (RNP-1 and RNP-2) are boxed.

$\operatorname{csp} D)$ are highly similar $(81 \%$ and $82 \%$ identity, respectively). Also the spacing between the two adjacent ORFs is similar for both tandem repeats (268 nt for cspA and $c s p B, 277 \mathrm{nt}$ for $c s p C$ and $c s p D$ ).

The five CSPs of $L$. lactis have a mutual identity of $52-85 \%$ at the amino acid level. The identity to the major CSPs, $\operatorname{CspA}^{\mathrm{E}}$ and $\mathrm{CspB}^{\mathrm{B}}$, is about $45-65 \%$ and is lowest for CspA and CspC (Fig. 2, Table 3). The calculated molecular masses of the L. lactis CSPs range from $7 \cdot 1 \mathrm{kDa}$ for CspE to $7 \cdot 6 \mathrm{kDa}$ for CspA and CspC (Table 3). CspA and CspC have an unusually high pI (approximately 9) compared to other CSPs (approximately 5).

\section{Cold induction of csp genes}

Cells of L. lactis were cultured to the mid-exponential phase at $30^{\circ} \mathrm{C}$, after which they were subjected to a cold shock by resuspending in precooled GM17 medium $\left(10^{\circ} \mathrm{C}\right)$. The growth characteristics of the cold-shocked 
Table 3. Identity (\%), size of ORF in amino acids, molecular mass and pl of the L. lactis CSPs, CspAE and $\operatorname{CspB}^{\mathrm{B}}$

\begin{tabular}{|c|c|c|c|c|c|c|c|c|c|c|}
\hline & \multicolumn{7}{|c|}{ Identity (\%) } & \multirow{2}{*}{$\begin{array}{l}\text { Size } \\
\text { (aa) }\end{array}$} & \multirow{2}{*}{$\begin{array}{c}\text { Mol. } \\
\text { mass } \\
(\mathrm{kDa})\end{array}$} & \multirow[t]{2}{*}{ pI } \\
\hline & CspA & CspB & CspC & CspD & CspE & $\operatorname{CspA}^{\mathrm{E}}$ & $\operatorname{CspB}^{B}$ & & & \\
\hline CspA & . & 62 & 76 & 59 & 60 & 45 & 50 & 66 & $7 \cdot 6$ & $9 \cdot 2$ \\
\hline CspB & & . & 56 & 80 & 82 & 59 & 62 & 66 & $7 \cdot 3$ & 4.9 \\
\hline CspC & & & . & 52 & 52 & 48 & 47 & 66 & $7 \cdot 6$ & 9.6 \\
\hline CspD & & & & . & 85 & 64 & 65 & 66 & $7 \cdot 2$ & $4 \cdot 4$ \\
\hline CspE & & & & & . & 61 & 63 & 65 & $7 \cdot 1$ & $4 \cdot 6$ \\
\hline $\operatorname{CspA}^{\mathrm{E}}$ & & & & & & . & 61 & 70 & $7 \cdot 4$ & $5 \cdot 9$ \\
\hline $\mathrm{CspB}^{\mathrm{B}}$ & & & & & & & 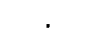 & 67 & $7 \cdot 4$ & $4 \cdot 3$ \\
\hline
\end{tabular}

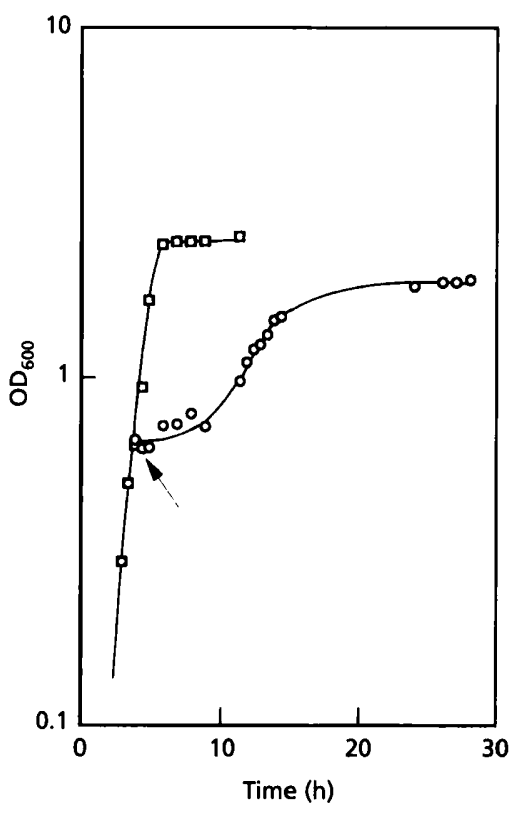

Fig. 3. Growth of L. lactis MG1363 at $30^{\circ} \mathrm{C}$ (squares) and after cold shock to $10^{\circ} \mathrm{C}$ (circles). The arrow indicates the time point of cold shock.

culture are shown in Fig. 3. A lag time of about $6-8 \mathrm{~h}$ after cold shock was observed, after which exponential growth was resumed with a lower growth rate (sixfold reduction) as compared to $30^{\circ} \mathrm{C}$. The amount of mRNA of the csp genes was monitored by Northern blotting at various times after cold shock (Fig. $4 a$; only shown for $\operatorname{csp} B$ ). Probes specific for each cold-shock gene were used (Table 2); the cross-hybridization for all probes was calculated and appeared to be maximally $6 \%$ with primer PEcspE and $c s p C$ (data not shown). Transcripts of about $300 \mathrm{nt}$ were detected for all csp genes, whereas for $\operatorname{csp} A$ and $\operatorname{csp} C$ larger transcripts (about 450 and $350 \mathrm{nt}$, respectively) were also detected in small amounts ( $<5 \%$; see below).

The results of the Northern blotting of the csp genes, using $u s p 45$ as an internal control, established that $\operatorname{csp} B$ and $\operatorname{csp} D$ were induced about 40 - and 30 -fold, re- (a)
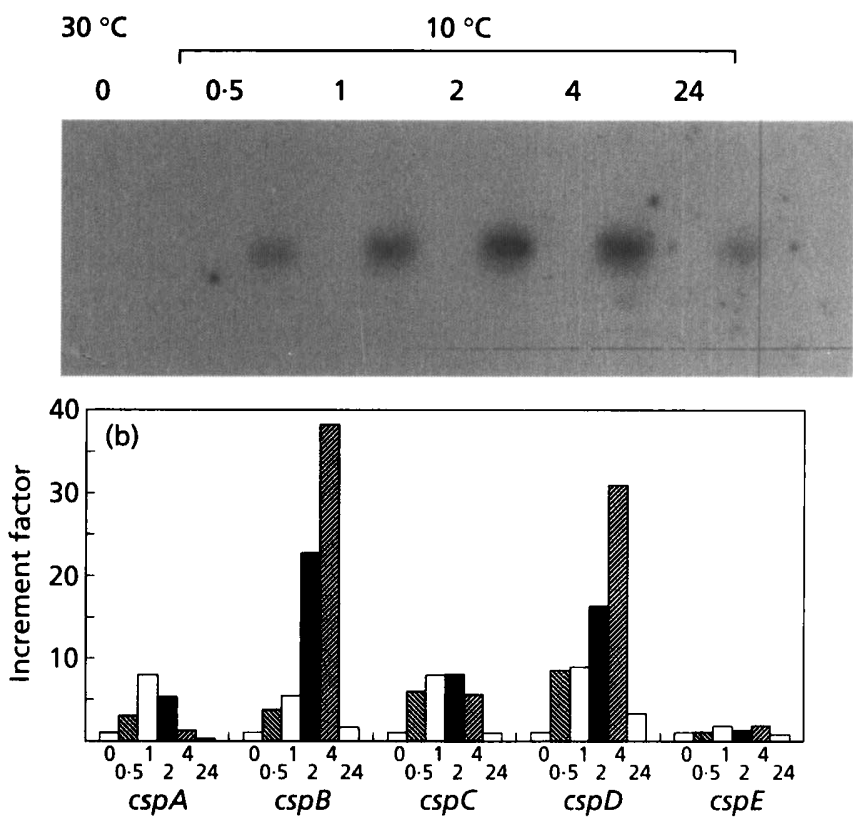

Fig. 4. (a) Northern blot of RNA extracted at $0,0.5,1,2,4$ and $24 \mathrm{~h}$ after cold shock, hybridized with a probe specific for $\operatorname{csp} B$ (Table 2). The transcript size is about $300 \mathrm{nt}$. (b) Increase in mRNA levels at different times after cold shock relative to $t=0$ $\left(30^{\circ} \mathrm{C}\right)$. Correction for mRNA amounts was performed using usp45 (Van Asseldonk et al., 1990) as a standard.

spectively, at $10^{\circ} \mathrm{C}$, whereas $\operatorname{csp} A$ and $\operatorname{csp} C$ were induced about 10 -fold compared to the level at $30^{\circ} \mathrm{C}$ (Fig. $4 \mathrm{~b})$. At $30^{\circ} \mathrm{C}(t=0)$ a relatively high $c s p E$ mRNA level was detected compared to the other four $c s p$ genes, but $c s p E$ seemed not to be induced significantly at low temperature (Fig. 4b). Strikingly, the time at which maximal mRNA levels were found was different for the cold-induced $c s p$ genes. $c s p A$ and $\operatorname{cs} p C$ reached maximal accumulation at 1-2 h after cold shock whereas for $\operatorname{csp} B$ and $c s p D$ maximal accumulation occurred at about 2-4 h after cold shock (Fig. 4b). The mRNA levels of $\operatorname{csp} A, \operatorname{csp} B, \operatorname{csp} C$ and $c s p D$ were decreased at $8 \mathrm{~h}$ after cold shock (data not shown), when exponential growth was resumed (Fig. 3). Other stress conditions, such as 

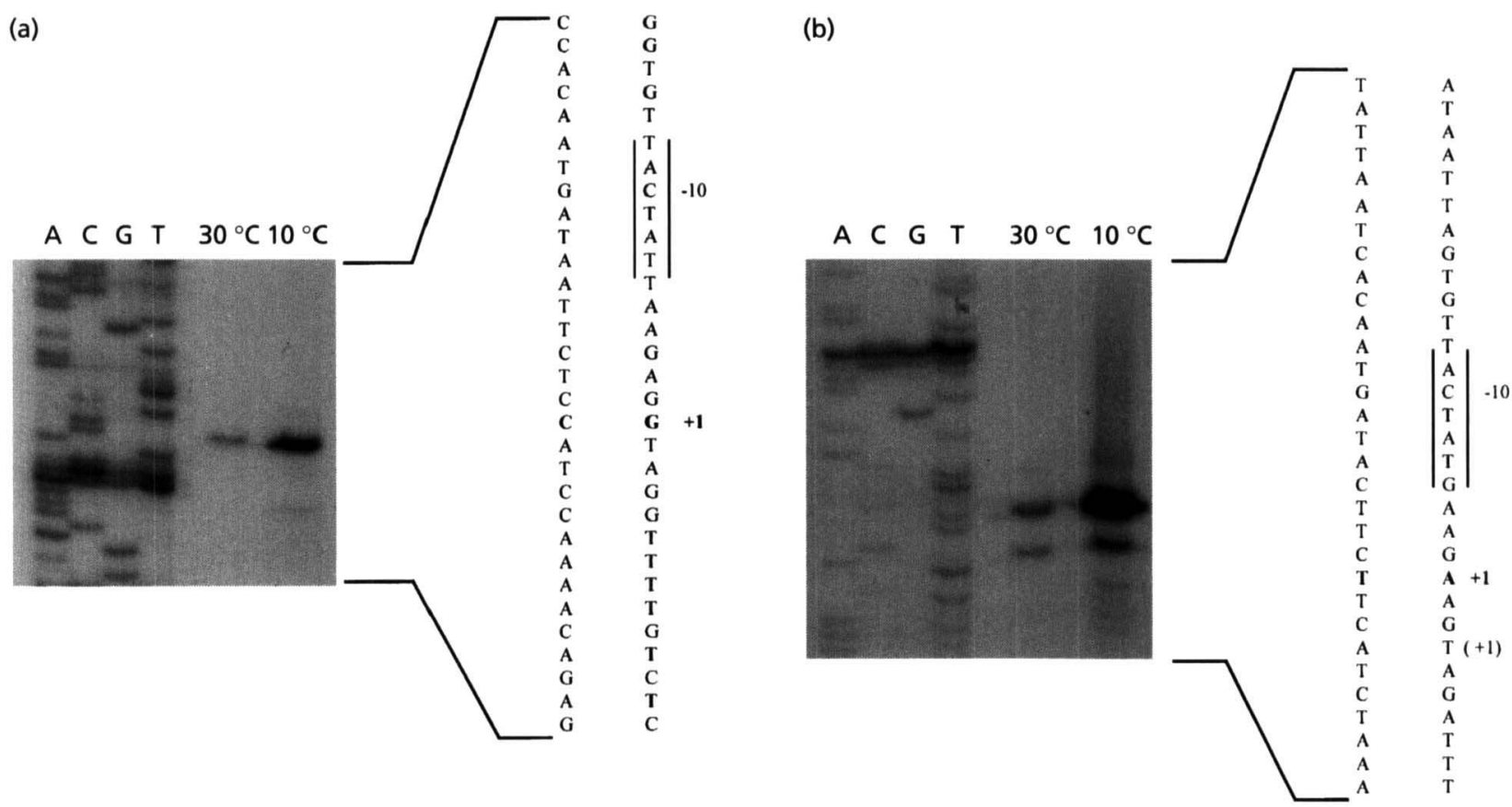

Fig. 5. Primer extension experiments for (a) $\operatorname{csp} C$ and (b) $\operatorname{cspD}$. Sequence ladders are indicated on the left. RNA samples were taken at the mid-exponential growth phase at $30^{\circ} \mathrm{C}$ and at $2 \mathrm{~h}$ after cold shock to $10^{\circ} \mathrm{C}$. The nucleotide sequences, the -10 promoter regions and the transcription starts are indicated on the right.

heat stress $\left(10 \min 42^{\circ} \mathrm{C}\right)$, salt stress $(10 \min 0.5 \mathrm{M}$ $\mathrm{NaCl}$ ), low-pH stress (10 min $\mathrm{pH} 4 \cdot 0$, adjusted with lactic acid) or stationary-phase conditions ( $2 \mathrm{~h}$ after reaching stationary phase) did not result in increased mRNA levels of any of the csp genes (data not shown).

\section{Identification of promoter regions}

Using the primer extension technique, transcription start points of the $c s p$ genes were identified (Fig. 5 ; only shown for $c s p C$ and $c s p D$ ); they are indicated in Fig. 6. For $\operatorname{csp} D$ a double transcription start was found: a major start at the indicated A-residue and a minor start at the $\mathrm{T}$-residue three bases downstream. For each $c s p$ gene, transcripts were detectable at $30^{\circ} \mathrm{C}$, and for $c s p A$, $c s p B, c s p C$ and $c s p D$ increased amounts of transcript were found at $10^{\circ} \mathrm{C}$. The same transcription start points were identified at high and low temperature. Northern blotting showed that the mRNA size for the different $c s p$ genes is about $300 \mathrm{nt}$, which corresponds well with the detected transcription starts and the putative terminators $[\Delta G=-6,-10,-8,-8$ and $-8 \mathrm{kcal} \mathrm{mol}^{-1}(-25,-42,-33,-33$ and $-33 \mathrm{~kJ} \mathrm{~mol}^{-1}$ ) for $\operatorname{csp} A, \operatorname{csp} B, \operatorname{csp} C, \operatorname{csp} D$ and $c s p E$, respectively]. For $c s p A$ and $c s p C$ hairpin structures $\left[\Delta G=-10\right.$ and $-14 \mathrm{kcal} \mathrm{mol}^{-1}(-42$ and $-59 \mathrm{~kJ}$ $\mathrm{mol}^{-1}$ ), respectively] were found further downstream the ORFs, for which the size of the mRNA corresponds with larger transcripts that were detected in small amounts (only detected after prolonged exposure of the blots to X-ray films). When DNA fragments containing parts of the csp genes and the region between the
$-35$

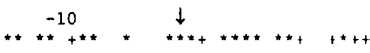

CsPA (-45) AAAGCATAATTTCACTTTCTATCAGAGAGGTGGTAGTATCAAGAGGTAGGTTTT-GTCGTGAGT

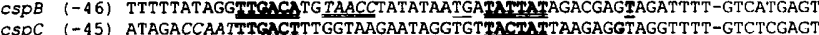
CSPC $(-45)$ ATAGACCAATTTGACTTTGGTAAGAATAGGTGTTACTATTAAGAGGTAGGTTTT-GTCTCGAGT

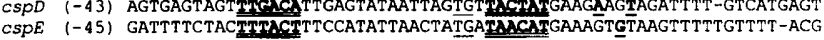
CSPE (-45) GATTTTCTACTIRACRTTCCATATTAACTATGA TMCAFGAAGTGTAAGTTTTTGTTTT -ACG

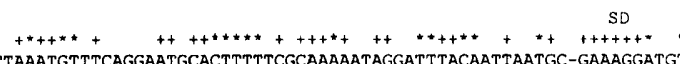
CsPA $(+19)$ TTAAATGTTTCAGGAATGCACTTTTTCGCAAAAATAGGATTTACAATTAATGC-GAAAGGATGT cspB $(+18)$-TAAATGTATATTATATTCACTTTT-CACAAAATAAGG-TTTACAATTTTTGTTGAAAGGAAAT $\begin{array}{lll}c s p C & (+19) & \text { TTAAATGTTTTAGGAATGCACTTTTTCGCAAAA-TAGGATTTACAGATGATGC-GAAAGGATC } \\ c s p D & (+21) & \text {-AAAATGTTTTATAGATTCACTTTT-CGCAAAATGAG-ATTTACAATTTTTGTCGAAAGGAAAT }\end{array}$ $\begin{array}{lll}c s p D & (+21) & \text {-AAAATGTTTTATAGATTCACTTTT-CGCAAAATGAG-ATTTACAATTTTTGTCGAAAGGAAAT } \\ c s p E & (+19) \text { ATTA--GTTCTGTG-----CTTTTGGGTCATTCCT-ATT--CAAGAAATTAGATTTACAAAT }\end{array}$ $+$

CsPA (+81) ATTAAGATCATAAATGGACACTMNATGGTTCAMTATGC CSPB (+79) AATTAATATEACANACCAACTGTANAATGGTPTAATCCA CSPC (+80) ATTATATGMTIAAACCAACMATAAATTGGTTTMACECCEA CSPD (1+82) AAATATTATCSCAMATGGAACACTMUATGGTTTAACGCT CSPE $(+73)$ TTATAAA ATAAGGAGTACCAAAAMTOCCACMACCMACTC

Fig. 6. Alignment of the nucleotide sequence of the csp promoters and the $5^{\prime}$ UTR sequences of the lactococcal csp genes. The translated regions are indicated in bold; SDsequences are double-underlined; transcription starts are underlined and in bold (and indicated with an arrow); -35 and -10 regions are double-underlined and in boid; TG dinucleotides ( -16 region) are underlined; start codons are underlined, and in bold italic; Y-box motifs are double underlined and in italic. Identical nucleotides in all five csp genes are indicated with *; identical nucleotides in the four cold-induced csp genes only are indicated with + . Nucleotides are numbered from their +1 transcription starts.

clustered $c s p$ genes were used as probes, only transcripts of about $300 \mathrm{nt}$ were detected, indicating that the $c s p$ genes located in tandem repeats are monocistronic.

The detected transcription start sites allowed identification of -35 and -10 promoter regions of the $c s p$ genes (Fig. 6). The promoter regions are $67-92 \%$ 
identical to the established consensus sequences of $L$. lactis (De Vos \& Simons, 1994). The consensus $17 \mathrm{bp}$ spacing between the -35 and -10 regions is found for all lactococcal csp promoters (Fig. 6). The non-coldinduced $c s p E$ gene has the lowest similarity (4 nt mismatches) with the consensus promoters, whereas the promoter regions of the cold-induced $c s p$ genes are less different from the consensus promoter regions $(3,3,2$ and $1 \mathrm{nt}$ mismatches for $c s p A, c s p C, c s p D$ and $c s p B$, respectively). In the promoter regions of $c s p C$ and $c s p B$ complementary sequences (CCAAT) of the Y-box motifs (ATTGG) are present (Fig. 6). Several of these motifs were also found further up- and downstream of the promoter regions of the other lactococcal $c s p$ genes.

The $5^{\prime}$-untranslated leader regions $\left(5^{\prime}\right.$ UTRs) of the cold-induced $\operatorname{csp} A, \operatorname{csp} B, \operatorname{csp} C$ and $\operatorname{csp} D$ genes are highly identical (approximately $60 \%$ ) whereas the identity with this region of the non-cold-inducible $c s p E$ is much lower (about 30\%; Fig. 6). Furthermore, the $5^{\prime}$ UTR of $c s p E$ ( $94 \mathrm{nt}$ ) is slightly longer than those of the other lactococcal $c s p$ genes $(86,84,83$ and $87 \mathrm{nt}$ for $c s p A, \operatorname{csp} B, \operatorname{csp} C$ and $c s p D$, respectively). The $5^{\prime}$ UTRs of all lactococcal csp genes appear to be rich in secondary structure, encompassing the entire region as calculated by the method of Zuker \& Stiegler (1981).

\section{DISCUSSION}

A family of five genes, named $c s p A, c s p B, c s p C, c s p D$ and $\operatorname{csp} E$, encoding putative CSPs was cloned from $L$. lactis MG1363 and it appeared that these $c s p$ genes were organized in clusters. $c s p A$ and $c s p B$ as well as $c s p C$ and $c s p D$ are located in a tandem repeat whereas $c s p E$ was found as a single gene. To our knowledge, a clustered organization of csp genes has never been observed before (Graumann et al., 1996; Lee et al., 1994; Mayo et al., 1997; Mayr et al., 1996; Willimsky et al., 1992).cspB is identical to the $\operatorname{csp} B$ gene that was recently obtained from $L$. lactis AM2 using an inverse PCR strategy (Chapot-Chartier et al., 1997).

The five $c s p$ genes can be grouped based on sequence analysis: a group consisting of $c s p A$ and $c s p C$ (the first genes in the tandem repeats); and a group consisting of $c s p B, c s p D$ and $c s p E$. Members within these groups code for highly similar proteins (about $80 \%$ identity) whereas the identity between these two groups is only about $55 \%$. High similarity $(45-65 \%$ identity) was also observed with the sequences of the major CSPs CspA ${ }^{\mathrm{E}}$ and $\mathrm{CspB}^{\mathrm{B}}$, and was lowest for CspA and CspC. The residues important for single-stranded DNA binding of $\mathrm{CspA}^{\mathrm{E}}$ and $\mathrm{CspB}^{\mathrm{B}}$ (Newkirk et al., 1994; Schröder et al., 1995) are highly conserved in CspB, CspD and CspE, whereas in CspA and CspC some additional residues are different from the $\mathrm{CspA}^{\mathrm{E}}$ and $\mathrm{CspB}^{\mathrm{B}}$ DNA-binding residues. The RNA-binding RNP-1 (consensus KGFGF) and RNP-2 (consensus VFVH) motifs (Jones \& Inouye, 1994; Schindelin et al., 1993; Schröder et al., 1995) are also found in the L. lactis CSPs although some differences are observed. Interestingly, the $\mathrm{pI}$ values of CspA and CspC (9.2 and 9.6, respectively) are much higher than those of the other CSPs (approximately 4.5) due to the presence of more basic residues ( 8 and 11 for CspA and CspC, respectively, compared to 7 for CspB, CspD and CspE) and the presence of 4 tyrosine residues for $\mathrm{CspA}$ and $\mathrm{CspC}$ and no tyrosine residues in $\mathrm{CspB}$, CspD and CspE. This high $\mathrm{pI}$ of CspA and CspC might result in an improved nucleic acid binding capacity since these proteins do not need to overcome charge repulsion when approaching nucleic acids (Schröder et al., 1995). Furthermore, protein 3-D modelling based on the crystal structure of $\operatorname{CspA}^{\mathrm{E}}$ and $\mathrm{CspB}^{\mathrm{B}}$ (Schindelin et al., 1993, 1994) revealed a similar $\beta$-barrel structure formed by five $\beta$-strands for all five lactococcal CSPs (J. A. Wouters, unpublished results).

For all csp genes transcripts of about $300 \mathrm{bp}$ were found and no combined transcripts were found for the csp genes located in tandem repeats. Furthermore, Northern blotting revealed increased mRNA levels for the csp genes at different times after cold shock, indicating that regulation of these genes takes place at the transcriptional level. Maximal induction of mRNA was approximately 40 - and 30 -fold for $c s p B$ and $c s p D$, respectively, whereas the mRNA level of $c s p A$ and $c s p C$ increased approximately 10 -fold. $c s p E$ was not induced at $10^{\circ} \mathrm{C}$. A differential expression in time after cold shock was observed for the different $c s p$ genes. mRNA levels of $\operatorname{csp} A$ and $\operatorname{csp} C$ increase shortly after cold shock (in the first $2 \mathrm{~h}$ ) whereas $c s p B$ and $c s p D$ mRNA levels are highest at $4 \mathrm{~h}$ after cold shock. Possibly the more basic CSPs, CspA and CspC, are involved in the regulation of the expression of their counterparts CspB and CspD located further downstream. Since no mRNA induction was observed upon exposure to other stress conditions, such as heat, salt, low $\mathrm{pH}$ and stationary phase, it is concluded that these $c s p$ genes, with the exception of $\operatorname{csp} E$, might play a specific role in low-temperature adaptation. Recently, it was shown that the non-coldinduced $c s p D$ gene of the $E$. coli CspA family is in fact induced under stationary-phase conditions (Yamanaka \& Inouye, 1997).

Recent studies indicate that the $5^{\prime}$ UTR plays an important role in the stability of the E. coli cspA transcript (Fang et al., 1997) and the regulation of $\mathrm{CspA}^{\mathrm{E}}$ expression after cold shock (Jiang et al., 1996). Although the $5^{\prime}$ UTRs of the lactococcal csp genes are not as exceptionally long (83-94 nt) as this region of the E. coli cspA (159 nt; Goldstein et al., 1990), they might play a similar role. Most intriguing in this respect is the finding that the $5^{\prime}$ UTRs of the four cold-induced lactococcal csp genes are highly similar but that clear differences are observed in this sequence of the noncold-induced $c s p E$ gene, indeed suggesting a regulatory function of this leader.

Future research will focus on the differential expression, the clustered organization and the regulation of the newly described csp genes in L. lactis. The physiological role of the L. lactis CSPs will be studied using single and multiple overexpression constructs and using strains with disrupted $c s p$ genes. 


\section{ACKNOWLEDGEMENTS}

We thank Tomasz Oczkowski and Girbe Buist for their technical assistance with cloning of $c s p E$.

\section{REFERENCES}

Brandi, A., Pietroni, P., Gualerzi, C. O. \& Pon, C. L. (1996). Posttranscriptional regulation of CspA expression in Escherichia coli. Mol Microbiol 19, 231-240.

Casadaban, M. J. \& Cohen, S. N. (1980). Analysis of gene control signals by DNA fusion and cloning in Escherichia coli. J Mol Biol 138, 179-207.

Chapot-Chartier, M. P., Schouler, C., Lepeuple, A. S., Gripon, J. C. \& Chopin, M. C. (1997). Characterization of $\operatorname{csp} B$, a cold-shockinducible gene from Lactococcus lactis, and evidence for a family of genes homologous to the Escherichia coli cspA major cold shock gene. J Bacteriol 179, 5589-5593.

De Vos, W. M. \& Simons, G. F. M. (1994). Gene cloning and expression systems in lactococci. In Genetics and Biotechnology of Lactic Acid Bacteria, pp. 52-105. Edited by M. J. Gasson and W. M. de Vos. London: Blackie Academic \& Professional.

Fang, L., Jiang, W., Bae, W. \& Inouye, M. (1997). Promoterindependent cold-shock induction of $c s p A$ and its derepression at $37^{\circ} \mathrm{C}$ by mRNA stabilization. Mol Microbiol 23, 355-364.

Gasson, M. J. (1983). Plasmid complements of Streptococcus lactis NCDO 712 and other lactic streptococci after protoplastinduced curing. J Bacteriol 154, 1-9.

Goldstein, J., Pollitt, N. S. \& Inouye, M. (1990). Major cold shock protein of Escherichia coli. Proc Natl Acad Sci USA 87, 283-287.

Graumann, P. \& Marahiel, M. A. (1994). The major cold shock protein of Bacillus subtilis CspB binds with high affinity to the ATTGG- and CCAAT-sequences in single stranded oligonucleotides. FEBS Lett 338, 157-160.

Graumann, P., Schröder, K., Schmid, R. \& Marahiel, M. A. (1996). Cold shock stress-induced proteins in Bacillus subtilis. J Bacteriol 178, 4611-4619.

Graumann, P., Wendrich, T. M., Weber, M. H. W., Schröder, K. \& Marahiel, M. A. (1997). A family of cold shock proteins in Bacillus subtilis is essential for cellular growth and for efficient protein synthesis at optimal and low temperatures. Mol Microbiol 25, 741-756.

Jiang, W., Fang, L. \& Inouye, M. (1996). The role of the 5 '-end untranslated region of the mRNA for CspA, the major cold-shock protein of Escherichia coli, in cold-shock adaptation. J Bacteriol 178, 4919-4925.

Jiang, W., Hou, Y. \& Inouye, M. (1997). CspA, the major coldshock protein of Escherichia coli, is an RNA chaperone. $J$ Biol Chem 272, 196-202.

Jones, P. G. \& Inouye, M. (1994). The cold shock response - a hot topic. Mol Microbiol 11, 811-818.

Jones, P. G. \& Inouye, M. (1996). RbfA, a 30 S ribosomal binding factor, is a cold-shock protein whose absence triggers the coldshock response. Mol Microbiol 21, 1207-1218.

Jones, P. G., VanBogelen, R. \& Neidhardt, F. C. (1987). Induction of proteins in response to low temperature in Escherichia coli. J Bacteriol 169, 2092-2095.

Jones, P. G., Krah, R., Tafuri, S. R. \& Wolffe, A. P. (1992). DNA gyrase, CS7.4, and the cold shock response in Escherichia coli. J Bacteriol 174, 5798-5802.

Jones, P. G., Mitta, M., Kim, Y., Jiang, W. \& Inouye, M. (1996). Cold shock induces a new major ribosomal-associated protein which unwinds double-stranded RNA in Escherichia coli. Proc Natl Acad Sci USA 93, 76-80.

Kim, W. S. \& Dunn, N. W. (1997). Identification of a cold shock gene in lactic acid bacteria and the effect of cold shock on cryotolerance. Curr Microbiol 35, 59-63.

Kuipers, O. P., Boot, H. J. \& De Vos, W. M. (1991). Improved sitedirected mutagenesis method using PCR. Nucleic Acids Res 19, 4558.

Kuipers, O. P., Beerthuyzen, M. M., Siezen, R. J. \& De Vos, W. M. (1993). Characterization of the nisin gene cluster nis ABTCIPR of Lactococcus lactis : requirement of expression of the nis $A$ and nisI genes for development of immunity. Eur J Biochem 216, 281-291. Landsman, D. (1992). RNP-1, an RNA-binding motif is conserved in the DNA-binding cold shock domain. Nucleic Acids Res 20, 2861-2864.

LaTeana, A., Brandi, A., Falconi, M., Spurio, R., Pon, C. L. \& Gualerzi, C. O. (1991). Identification of a cold shock transcriptional enhancer of the Escherichia coli major cold shock gene encoding nucleoid protein H-NS. Proc Natl Acad Sci USA 88, 10907-10911.

Lee, S. J., Xie, A., Jiang, W., Etchegaray, J., Jones, P. G. \& Inouye, M. (1994). Family of the major cold-shock protein, CspA (CS7.4), of Escherichia coli, whose members show a high sequence similarity with the eukaryotic Y-box binding proteins. Mol Microbiol 11, 833-839.

Mayo, B., Derzelle, S., Fernandez, M., Leonard, C., Ferain, T., Hols, P., Suarez, J. E. \& Delcour, J. (1997). Cloning and characterization of cspL and cspP, two cold-inducible genes from Lactobacillus plantarum. J Bacteriol 179, 3039-3042.

Mayr, B., Kaplan, T., Lechner, S. \& Scherer, S. (1996). Identification and purification of a family of dimeric major cold shock protein homologs from the psychrotrophic Bacillus cereus WSBC10201. J Bacteriol 178, 2916-2925.

Nakashima, K., Kanamaru, K., Mizuno, T. \& Horikoshi, K. (1996). A novel member of the $\operatorname{csp} A$ family of genes that is induced by cold shock in Escherichia coli. J Bacteriol 178, 2994-2997.

Newkirk, K., Feng, W., Jiang, W., Tejero, R., Emerson, S. D., Inouye, M. \& Montelione, G. T. (1994). Solution of NMR structure of the major cold shock protein (CspA) from Escherichia coli: identification of a binding epitope for DNA. Proc Natl Acad Sci USA 91, 5114-5118.

Panoff, J.-M., Legrand, S., Thammavongs, B. \& Boutibonnes, P. (1994). The cold shock response in Lactococcus lactis subsp. lactis. Curr Microbiol 29, 213-216.

Rallu, F., Gruss, A. \& Maguin, E. (1996). Lactococcus lactis and stress. Antonie Leeuwenboek 70, 243-251.

Sambrook, J., Fritsch, E. F. \& Maniatis, T. (1989). Molecular Cloning: a Laboratory Manual, 2nd edn. Cold Spring Harbor, NY: Cold Spring Harbor Laboratory.

Sanders, J. W., Leenhouts, K., Haandrikman, A. J., Venema, G. \& Kok, J. (1995). Stress response in Lactococcus lactis: cloning, expression analysis and mutation of the superoxide dismutase gene. J Bacteriol 177, 5254-5260.

Sanger, F., Nicklen, S. \& Coulson, A. R. (1977). DNA sequencing with chain-terminating inhibitors. Proc Natl Acad Sci USA 74, 5463-5467.

Schindelin, H., Marahiel, M. A. \& Heinemann, U. (1993). Universal nucleic acid-binding domain revealed by crystal structure of the B. subtilis major cold-shock protein. Nature 364, 164-168.

Schindelin, H., Jiang, W., Inouye, M. \& Heinemann, U. (1994). Crystal structure of CspA, the major cold shock protein of Escherichia coli. Proc Natl Acad Sci USA 91, 5119-5123. 
Schröder, K., Graumann, P., Schnuchel, A., Holak, T. A. \& Marahiel, M. A. (1995). Mutational analysis of the putative nucleic acid-binding surface of the cold-shock domain, CspB, revealed an essential role of aromatic and basic residues in binding of singlestranded DNA containing the Y-box motif. Mol Microbiol 16, 699-708.

Van Alen-Boerrigter, I. J., Baankreis, R. \& De Vos, W. M. (1991). Characterization and overexpression of the Lactococcus lactis pep $N$ gene and localization of its product, aminopeptidase $\mathrm{N}$. Appl Environ Microbiol 57, 2555-2561.

Van Asseldonk, M., Rutten, G., Oteman, M., Siezen, R. J., De Vos, W. M. \& Simons, G. (1990). Cloning, expression in Escherichia coli and characterization of USP45, a gene encoding a highly secreted protein from Lactococcus lactis MG1363. Gene 95, 155-160.

Van Asseldonk, M., Simons, A., Visser, H., De Vos, W. M. \& Simons, G. (1993). Cloning, nucleotide sequence and regulatory analysis of the Lactococcus lactis dnaJ gene. J Bacteriol 175, 1637-1644.

Vos, P., Van Asseldonk, M., Van Jeveren, F., Siezen, R. J., Simons, G. \& De Vos, W. M. (1989). A maturation protein is essential for the production of active forms of Lactococcus lactis SK11 serine proteinase located in or secreted from the cell envelope. J Bacteriol 171, 2795-2802.

Wells, J. M., Wilson, P. W. \& Le Page, R. W. F. (1993). Improved cloning vectors and transformation procedure for Lactococcus lactis. J Appl Bacteriol 74, 629-636.

Willimsky, G., Bang, H., Fischer, G. \& Marahiel, M. A. (1992). Characterization of $c s p B$, a Bacillus subtilis inducible cold shock gene affecting cell viability at low temperatures. J Bacteriol 174, 6326-6335.

Yamanaka, K. \& Inouye, M. (1997). Growth-phase-dependent expression of $c s p D$, encoding a member of the CspA family in Escherichia coli. J Bacteriol 179, 5126-5130.

Zuker, M. \& Stiegler, P. (1981). Optimal computer folding of large RNA sequences using thermodynamics and auxiliary information. Nucleic Acids Res 9, 133-148.

Received 16 January 1998; revised 15 June 1998; accepted 7 July 1998. 